FOLIA POMERANAE UNIVERSITATIS TECHNOLOGIAE STETINENSIS

Folia Pomer. Univ. Technol. Stetin., Agric., Aliment., Pisc., Zootech. 2021, 358(57)1, 15-28

Review article

Received 17 Aug 2020

Revised 19 Oct 2020

Krystian A. OŁDAK

Accepted 31 Oct 2020

\title{
PROPOSAL OF THE MONITORING METHODOLOGY OF THE GREEN HAWKER Aeshna viridis Eversmann, 1836 (Odonata: Aeshnidae)
}

Faculty of Animal Breeding, Bioengineering and Conservation, Warsaw University of Life Sciences SGGW, Warszawa, Poland

\begin{abstract}
Aeshna viridis, a species of dragonfly of the family Aeshnidae, is listed in Appendix II of the Bern Convention as well as Annex IV of the Habitats Directive. The decline in the range and abundance of $A$. viridis is associated with a strong dependence of this species on the presence of Stratiotes aloides in the water body and results from a decrease in the number of suitable habitats. So far, attempts to develop a monitoring methodology for this species have been made in several European countries, including Sweden, Denmark and the Netherlands. This article presents a proposal for a monitoring methodology based on the evaluation of indicators of population condition in the form of exuviae density and number of adults, and indicators of habitat condition: the area of the water body covered by S. aloides, the presence of dense and undivided patches of $S$. aloides, succession in the water body and anthropopressure. The concept of population condition assessment methodology is based on observation of adult specimens and collecting exuviae, avoiding larvae sampling, which is invasive and associated with technical difficulties. The concept of the habitat condition assessment methodology, in turn, is based on strong association between $A$. viridis and $S$. aloides. It is proposed to monitoring $A$. viridis population on a minimum of several research areas within the country, on a two-year cycle. The presented proposal of the monitoring methodology requires pilot studies to be carried out within the $A$. viridis localities in order to determine the validity of assumptions made in the monitoring methodology.
\end{abstract}

Key words: Green Hawker, Aeshna viridis, monitoring.

\section{INTRODUCTION}

Aeshna viridis (Eversmann, 1836) is a species of dragonfly in the family Aeshnidae. It occurs from Siberia to the Netherlands (Dijkstra and Lewington 2014). A. viridis is listed in the Convention on the Conservation of European Wildlife and Natural Habitats (Annex II), as well as the Fauna-Flora-Habitats Directive (Annex IV). It is considered near threatened on the red list of European dragonflies (Kalkman et al. 2010). Representatives of this species can be found in lakes, shallow ponds with muddy bottoms, oxbow lakes, slowly flowing waters (Wendzonka 2005) and ditches in wet grasslands (de Jong 1999; Gerard 2006; Kastner et al. 2011; Kastner et al. 2018).

Corresponding author: Krystian A. Ołdak, Faculty of Animal Breeding, Bioengineering and Conservation, Warsaw University of Life Sciences - SGGW, Jana Ciszewskiego 8, 02-786 Warszawa, Poland, e-mail: odakkrystian@gmail.com 
The occurrence of Aeshna viridis is limited by its strong association with Stratiotes aloides (Linnaeus, 1753) (Peters 1987). Females of $A$. viridis lay their eggs on leaves of $S$. aloides and larvae live among leaves after hatching. The leaves provide larvae with protection against predation by fish or larvae of other dragonflies (Rantala et al. 2004; Suutari et al. 2004), as well as against cannibalism (Suhonen et al. 2013), while in the time before the metamorphosis, larvae emerge from the water and moult there too (Wendzonka 2005). In addition to protection against predation, $S$. aloides provides larvae with the right conditions for hibernation (Münchberg 1956; Mauersberger et al. 2005; Kastner et al. 2018) and optimal growth conditions due to the right temperature (Mauersberger et al. 2005; Kastner et al. 2018). It should be added that organisms living in the vicinity of this plant can also be a rich source of food (Tarkowska-Kukuryk 2006; Suutari et al. 2009). Females also rarely lay eggs on other water plants, for example Typha spp. or Sparganium spp. (Rantalainen and Kanervo 1928; Askew 1988; Rantala et al. 2004).

Aeshna viridis occurs mainly in the water bodies, in which Stratiotes aloides take the form of dense patches and cover an area of at least several $\mathrm{m}^{2}$ (Wendzonka 2005). Larvae of Aeshna viridis were found almost exclusively among the rosettes of this plant (Rantala et al. 2004), although studies in Sweden have shown that at least in this country the association between $A$. viridis and $S$. aloides is weaker and larvae were also found among other plants (Andersen et al. 2016). The minimum surface area of this plant enabling $A$. viridis to survive is $5 \mathrm{~m}^{2}$ (Glitz et al. 1989; Kastner et al. 2018) or 8-10 $\mathrm{m}^{2}$ (Mauersberger et al. 2005), while the optimal area is at least $50 \mathrm{~m}^{2}$ (Mauersberger et al. 2005; Kastner et al. 2018). Studies by Kastner et al. (2018) showed that the probability of the $A$. viridis occurring in the ditch is $90 \%$ when $S$. aloides covers an area of at least $46.2 \mathrm{~m}^{2}$ when the only predicted variable in a model was coverage of emerged $S$. aloides stands, and an area of at least $8.4 \mathrm{~m}^{2}$, when the variable of the width of the ditches was also used in the model.

The optimal density of Stratiotes aloides in a water body for A. viridis is about 20 plants per $\mathrm{m}^{2}$ (de Jong 1999). Density of $A$. viridis larvae increases with the increase of the area covered by $S$. aloides, which may result from higher survivability of larvae. They can avoid natural enemies more effectively under such conditions. The abundance and persistence of $A$. viridis population depends not only on the total area covered by $S$. aloides within the water body but also on the area of dense and undivided patches of this plant. The presence of a large and dense patches is more beneficial for the population of $A$. viridis than a larger number of smaller patches of the same total area (Suhonen et al. 2013). In inhabited ditches, females may also lay eggs in smaller patches if they are spatially connected to larger ones (Fliedner 1996; Kastner et al. 2011; Kastner et al. 2018).

A limiting effect of the water maintenance, sediment thickness and water temperature in March and August on the number of $A$. viridis exuviae in the area of ditches was observed. In the silt phase, which is the part of the ditch succession, $S$. aloides is gradually replaced by reeds; in such sites, females do not lay eggs (Kastner et al. 2018).

The decline in the range and abundance of $A$. viridis is associated with a strong dependence of this species on the presence of Stratiotes aloides in the water body and results from a decrease in the number of suitable habitats. (Rassi et al. 2001). According to Kastner et al. (2018), the protection of the $A$. viridis population is closely related to the preservation 
of $S$. aloides stands. There are five main threats to this plant. The first one is intensive water maintenance involving the destruction of water vegetation. Inappropriate water maintenance, accompanied by silting, may also present a risk. Other threats include changes in water chemistry and eutrophication, as well as drying of water bodies. The activity of animals is also important, including nutria, muskrats, waterfowl and cattle (Roelofs 1991; Smolders et al. 2003; Mauersberger et al. 2005; Klugkist et al. 2015; Kastner et al. 2016; Kastner et al. 2018). Eutrophication involving the accumulation of organic matter and overgrowth by other aquatic plants seems to pose a significant risk to $S$. aloides (Andersen et al. 2016).

Human activity also has a significant impact on the population of $A$. viridis. For example, the ditch cleaning, often involving the removal of $S$. aloides, as well as eggs and larvae of dragonflies, should undoubtedly be considered a risk (Brunken et al. 2012; Kastner et al. 2018). Due to the fact that $A$. viridis often occur in river valleys, the transformation of these areas or rivers regulation may result in the destruction of potential habitats of this species (Bernard et al. 2009; Buczyński et al. 2015). S. aloides in water bodies may also be destroyed by anglers (Borkowski 1999).

So far, attempts to develop a monitoring methodology for this species have been made in several European countries. The methodology developed in Sweden is based primarily on netting for larvae in water bodies overgrown with Stratiotes aloides. The research carried out using this method has allowed the discovery of new localities of Aeshna viridis and the method itself has been considered appropriate for monitoring this species in that country. The main advantage of this method is the possibility to netting for larvae regardless of the weather and season, as opposed to observing adult specimens. The disadvantages of this method in turn are that it is time consuming, more equipment and materials are needed, and that species identification is more difficult for larvae than for adults. Due to the need to collect and conserve larvae in some cases, for example as evidence of the discovery of a new locality outside its distribution range, this method can also be considered invasive (Karlsson 2018). A. viridis was also monitored in Sweden using a methodology based on both netting for larvae and adults observation. (Sahlén 2006; Andersen et al. 2016). According to Andersen et al. (2016), it is necessary to develop more straightforward methods of monitoring this species, since the species identification requires specialist knowledge of the colour pattern variation of larvae in the family Aeshnidae and adults can only be observed on sunny days. Additionally, such fieldwork is time consuming.

In Denmark, a methodology based on observation of adults and collection of exuviae was developed. In the case of the search within the ditches, transects of 1 kilometre length are established, with 500 meters to go along one of the ditches and the same distance back along the other. In the case of other standing waters, observations should be made around the water body in selected sections. The observations shall be conducted from mid-July to the first half of August, on warm and sunny days between noon and 4 pm. (Søgaard et al. 2011).

It is worth noting that in the Netherlands, attempts to determine the presence of Aeshna viridis based on the analysis of water samples for the detection of dragonfly DNA have been successful (Herder et al. 2013).

The aim of this work is to propose a monitoring methodology for Aeshna viridis, including both population condition and habitat condition assessment. 


\section{MATERIAL AND METHODS}

The Aeshna viridis monitoring methodology has been developed primarily on the basis of scientific publications on the biology of this species, especially its habitat preferences. The general scheme of the methodology and the form of its presentation have been taken from Polish handbooks on monitoring of other dragonfly species, Leucorrhinia pectoralis Charpentier, 1825 and Coenagrion ornatum Sélys, 1850 (Bernard 2012; Bernard and Michalczuk 2012). Tables presented in the paper were prepared on the basis of tables developed by Bernard (2012). It should be noted that the methodology described below is not based on the author's experience, is only a proposal and needs to be verified by field testing. Ranges of values presented in tables of indicators' valorisation were prepared on the basis of data provided by the following authors: Gerard (2006), Bernard (2012), Buczyński (2012), Frank (2014), and Kastner et al. (2018).

\section{RESULTS AND DISCUSSION}

The methodology developed for monitoring Aeshna viridis is based, among other things, on the collection of exuviae from water bodies overgrown by Stratiotes aloides and the counting of adults. The former is relatively simple and does not require any specialist knowledge, as the determination of the species for exuviae can be carried out using identification keys. Further advantages include the possibility of collecting exuviae also during unfavourable weather conditions, non-invasiveness and the fact that finding exuviae of the species is a proof of its successful reproduction in the water body. The identification of adults in the field is relatively simple compared to e.g., the identification of larvae (Karlsson 2018). According to Raebel et al. (2010), surveys based only on adult observation are associated with an overestimation of the number of species reproducing successfully and only a collection of exuviae should be used for biomonitoring. Bried et al. (2012), on the other hand, concluded from their research that "(...) exuvial surveys may lead to strong negative bias in richness estimation", so they predict that sampling the different stages of the dragonfly's life history provide the most reliable assessment.

For the purposes of Aeshna viridis monitoring methodology, conservation status indicators of this species have been developed, divided into population condition indicators and habitat condition indicators. The adopted indicators of the $A$. viridis population condition are presented in Table 1.

Table 1. Indicators of $A$. viridis population condition

\begin{tabular}{lll}
\hline \multicolumn{1}{c}{ Indicator } & Measurement unit & Method of measurement/ definition \\
\hline Exuviae density & number of exuviae/ $10 \mathrm{~m}^{2}$ & $\begin{array}{l}\text { average number of collected exuviae per } \\
10 \mathrm{~m}^{2} \text { of water body area }\end{array}$ \\
\hline Number of adults & number of adults/ $100 \mathrm{~m}$ & number of adults observed per $100 \mathrm{~m}$ transect \\
\hline
\end{tabular}


The method of valorisation of population condition indicators is presented in Table 2.

Table 2. Valorisation of $A$. viridis population condition indicators

\begin{tabular}{lccc}
\hline \multicolumn{1}{c}{ Indicator/ assessment } & FV & U1 & U2 \\
\hline Exuviae density & $\begin{array}{c}2,5-6.6 \text { (high) } \\
>6.6 \text { (very high) }\end{array}$ & $0.4-2.4$ (moderate) & $<0.4$ (low) \\
\hline Number of adults & $\geq 10$ (high) & $3-9$ (moderate) & $0-2$ (low) \\
\hline
\end{tabular}

FV - favorable, U1 - unfavorable/inadequate, U2 - unfavorable/ bad.

For each evaluation of the indicator a certain number of points should be awarded: for FV - 2 points, for $\mathrm{U} 1-1$ point, for U2 -0 points. The total assessment for the condition of the population is as follows: $3-4$ points $=F V, 2$ points $=U 1,1$ point $=U 2$.

The adopted habitat condition indicators are presented in Table 3.

Table 3. Indicators of $A$. viridis habitat condition

\begin{tabular}{lcl}
\hline \multicolumn{1}{c}{ Indicator } & Measurement unit & \multicolumn{1}{c}{ Method of measurement/ definition } \\
\hline $\begin{array}{l}\text { Area of the water body covered by } \\
\text { Stratiotes aloides }\end{array}$ & $\mathrm{m}^{2}$ & $\begin{array}{l}\text { determination of the approximate area covered by } \\
\text { S. aloides rosettes in a water body, to the nearest } \\
1 \mathrm{~m}^{2}\end{array}$ \\
\hline $\begin{array}{l}\text { Presence of dense and undivided } \\
\text { Stratiotes aloides patches }\end{array}$ & $\begin{array}{c}\text { descriptive } \\
\text { indicator }\end{array}$ & $\begin{array}{l}\text { three-stage scale adopted for the monitoring of this } \\
\text { species }\end{array}$ \\
\hline Succession in a water body & $\begin{array}{l}\text { descriptive } \\
\text { indicator }\end{array}$ & $\begin{array}{l}\text { three-stage scale adopted for the monitoring of this } \\
\text { species }\end{array}$ \\
\hline Anthropopressure & $\begin{array}{l}\text { descriptive } \\
\text { indicator }\end{array}$ & $\begin{array}{l}\text { three-stage scale adopted for the monitoring of this } \\
\text { species }\end{array}$ \\
\hline
\end{tabular}

The method of valorisation of habitat condition indicators is presented in Table 4.

Table 4. Valorisation of habitat condition indicators

\begin{tabular}{lccc}
\multicolumn{1}{c}{ Indicator/ assessment } & FV & U1 & U2 \\
\hline $\begin{array}{l}\text { The area of the water body covered by } \\
\text { Stratiotes aloides }\end{array}$ & $>40 \mathrm{~m}^{2}$ & $8-40 \mathrm{~m}^{2}$ & $<8 \mathrm{~m}^{2}$ \\
\hline $\begin{array}{l}\text { Presence of dense and undivided } \\
\text { Stratiotes aloides patches }\end{array}$ & optimal habitat & acceptable habitat & marginal habitat \\
\hline Succession in a water body & optimal habitat & acceptable habitat & marginal habitat \\
\hline Anthropopressure & low & moderate & high \\
\hline
\end{tabular}

FV - favorable, U1 - unfavorable/ inadequate, U2 - unfavourable/ bad.

The first population condition indicator presented in Table 4, i.e. "area of the reservoir covered by $S$. aloides", indicates how large the area in the water body is covered by a water plant absolutely crucial for the presence and survival of $A$. viridis.

The indicator "presence of dense and undivided Stratiotes aloides patches" indicates the extent to which a plant overgrown with a water body forms dense, undivided patches with a relatively large area in contrast to smaller, unconnected patches. A three-stage descriptive 
scale was used here: "optimal habitat" - $S$. aloides covering the water body forms a single dense, continuous and undivided patch; "acceptable habitat" - $S$. aloides forms smaller patches, but spatially connected with each other; "marginal habitat" - $S$. aloides is located in the water body in the form of small, unconnected patches.

The indicator "succession in a water body" is important due to the direct impact of this process on $S$. aloides, the decline of which in turn threatens the population of $A$. viridis. A three-stage descriptive scale was used here: "optimal habitat" - no overgrowing of the water body, reduction of the area covered by $S$. aloides or its replacement by other water plants, including reeds, is observed; "acceptable habitat" - a slight overgrowing of the water body is observed; "marginal habitat" - the water body is clearly overgrown, with a reduction in the area covered by $S$. aloides; it is replaced by other water plants, mainly reeds. It should be noted that a reliable assessment can only be made on the second and subsequent visits to a particular water body.

The "anthropopressure" indicator describes direct and indirect human impact on a water body. A three-stage scale was used here. A "low" assessment - no activities are carried out within the habitat to clean water bodies or ditches, to transform the land or to regulate rivers, or to carry out any other work that may cause the land to dry out or pollute water. The use of the water body by the anglers is limited to a minimum or is completely absent. "Moderate" anthropopressure means that the activities carried out within the habitat are not intensive and have little influence on its condition. No river regulation work is conducted within the habitat and the land is not transformed in any other way. The use of the water body by the anglers is not very intensive. "High" anthropopressure means that river regulation work is conducted within the habitat or the land is being transformed in another way. Water bodies or ditches are regularly cleaned and/ or work is carried out within them that may cause damage to water plants or changes in water chemistry and eutrophication. The use of the water body by anglers can be described as intensive.

The following number of points should be given for assessments of habitat condition indicators: for $\mathrm{FV}-2$ points, for $\mathrm{U} 1-1$ point, for $\mathrm{U} 2-0$ points. The total assessment for the habitat condition is as follows: $\mathrm{FV}=7-8$ points, $\mathrm{U} 1=5-6$ points, $\mathrm{U} 2=1-4$ points.

The assessment of the condition of a species should also take into account its conservation prospects. They should be assessed by an expert. The assessment should take into account the current condition of the population and habitat of $A$. viridis as well as the chances of population and habitat conservation in relation to the observed negative impacts and potential threats. The "conservation prospects" parameter can be assessed as good or excellent (FV), unsatisfactory (U1) or bad (U2).

The overall assessment of the conservation status of $A$. viridis should take into account the population condition, the condition of the habitat and the conservation prospects. For each component assessed as "FV" 2 points are awarded, for U1 - 1 point and for U2 - 0 points. The overall assessment is as follows: $5-6$ points $=\mathrm{FV}, 3-4$, points $=\mathrm{U} 1,1-2$ points $=\mathrm{U} 2$. It should be added that the locality should not be assessed as "FV" if the "number of adults" or "exuviae density" indicators were evaluated as "U1".

A.viridis monitoring should be carried out in at least several research areas within the country. 
Valorisation of indicators of population and habitat condition involves carrying out specific field work. The assessment of the indicator "exuviae density" requires the collection of exuviae from $S$. aloides leaves protruding above water, from an area of about $50 \mathrm{~m}^{2}$. It is worth noting that although the water bodies which are inhabited by $A$. viridis are usually relatively shallow, they often contain a significant amount of hydrated bottom sediments. The depth in such places can reach even 2 metres (Bernard 2012). It is necessary to recognise the situation in the water body before starting to collect exuviae. In many cases it is advisable to use waders and sometimes it is necessary to use a boat. Whenever direct collection is not possible for various reasons, a long bamboo stick with a piece of thick double-sided adhesive tape on top should be used - exuviae stick quite easily to the adhesive tape, but they should be peeled off as soon as possible (Bernard 2012). During the collection of exuviae, appropriate containers will be needed, for example urine containers. This type of field work should be carried out on selected dates from mid-July to mid-August (Søgaard et al. 2011). If the number of exuviae collected is low, the collecting should be repeated a few days later. It is worth adding that although theoretically the collecting of exuviae can also be done during unfavourable weather conditions, it is definitely worth doing it in good weather. Exuviae may be washed off by rain or blown off in winds (Raebel et al. 2010). The determination of the species for exuviae can be carried out using identification keys.

Adults should be observed on sunny, warm days in the afternoon (Søgaard et al. 2011), although $A$. viridis can be active at dawn too and this activity also includes reproductive behaviour (Borkenstein et al. 2016). Males of this species can be observed during flights over $S$. aloides patches, while the females come to the water body only to lay eggs (Sternberg 2000; Bernard et al. 2009; Dijkstra and Lewington 2014; Kalkman et al. 2015; Pawlak 2019). The observer counts the adults, walking along the transect and stopping every few meters. The length of the transect should be about $100 \mathrm{~m}$. To observe flying males it is necessary to use binoculars. The observer should also look for females ovipositing in $S$. aloides leaves. Counting of flying males must be carried out carefully so as not to duplicate specimens. Adults in tandem or copulation should also be taken into account. Each count within a transect should be carried out twice, with the higher number of specimens observed being considered as a result. Observations of adults shall be carried out as part of one or two inspections on selected dates from mid-July to mid-August (Søgaard et al. 2011). A second control is needed when very few individuals were observed during the first one, as this may have been the result of a coincidence. The highest number of individuals observed is considered as the result. The observer should determine the geographical coordinates of the locality using a satellite navigation device.

The habitat of the species should be described in as many details as possible. It is important to obtain information on the type of water body, its surface, water depth and physico-chemical properties of water. The presence of other protected or valuable species should also be recorded. All this information should be recorded on the observation sheets. It is also important to make photographic documentation of the habitat.

Determining the indicator "surface of the water body covered by $S$. aloides" requires measurements of the two sides of $S$. aloides patch using a measuring tape. The help of another person is often needed. $50 \mathrm{~m}$ surveyors tape measure is long enough. $S$ aloides overwinters 
on the water body bottom and emerges in spring (Smolders et al. 2003; Strzałek and Koperski 2009) so attempts to measure the area covered by the plant should be made in late spring or summer.

The determination of the indicator "presence of dense and undivided Stratiotes aloides patches" consists in looking at the reservoir from several observation points and assessing whether $S$. aloides forms one dense patch or is divided into several smaller patches. The observer should also assess whether the patches are spatially connected to each other.

The determination of the indicator "succession in a water body" consists in the assessment of the degree of overgrowing of water body, reduction of the area of $S$. aloides patches and its replacement by other water plants. It is necessary to take photographs which will serve to compare the situation in previous and subsequent years.

The assessment of the "anthropopressure" indicator is made on the basis of direct observation of all works carried out within the habitat or the use of the water body by anglers. It is also worth making an attempt to obtain information from the reservoir manager, as well as from local residents or other available sources.

It is proposed to monitoring $A$. viridis population and habitat on a two-year cycle. This can be justified by the possibility of relatively rapid changes related to succession or drying out of shallow water bodies, which are usually inhabited by $A$. viridis.

Table 5 shows an example of a completed species observation sheet.

Table 5. Example of completed species observation sheet

\begin{tabular}{|c|c|}
\hline Species code and its name & $\begin{array}{l}\text { species code according to the European Union's Habitats Directive, } \\
\text { English and Latin name, name of author according to current nomenclature } \\
1048 \text { Green Hawker Aeshna viridis Eversmann, } 1836\end{array}$ \\
\hline Locality name & name of the monitored locality \\
\hline $\begin{array}{l}\text { Protected areas in which the site } \\
\text { is located }\end{array}$ & $\begin{array}{l}\text { Natura 2000, national and landscape parks, nature reserves, and others } \\
\text { none }\end{array}$ \\
\hline Geographical coordinates & $\begin{array}{l}\text { enter geographical coordinates (GPS) } \\
\text { N 52 } 12^{\prime} 32.4^{\prime \prime} ; \text { E } 21^{\circ} 35^{\prime} 00.1^{\prime \prime}\end{array}$ \\
\hline Altitude above sea level & $\begin{array}{l}\text { specify the altitude above sea level of the site } \\
112 \mathrm{~m} \text { above sea level }\end{array}$ \\
\hline Area of the site & $\begin{array}{l}\text { specify the area of the site }\left(\mathrm{ha} / \mathrm{a} / \mathrm{m}^{2}\right) \\
0.41 \mathrm{ha}\end{array}$ \\
\hline Position description & $\begin{array}{l}\text { provide a description allowing identification in the field } \\
\text { The water body is located about } 50 \mathrm{~m} \text { north of the Dworski Park } \\
\text { in Pogorzel, Mińsk Poviat. In Pogorzel turn into Parkowa Street; } \\
\text { the reservoir is located a few meters from the road... }\end{array}$ \\
\hline $\begin{array}{l}\text { Description of the species' habitat } \\
\text { in the locality }\end{array}$ & $\begin{array}{l}\text { habitat description } \\
\text { Retention reservoir built } 20 \text { years ago. A small park in close proximity. } \\
\text { The water body has an elongated shape, its area is about } 0.075 \text { ha. } \\
\text { Moderately eutrophic water body. Slow succession is observed. Clear } \\
\text { water. A large part of the water body is covered by } S \text {. aloides. Other } \\
\text { water plants: Typha latifolia, Carex sp. } \\
\text { Counting of adults on } 27 \text { July and } 12 \text { August on } 100 \mathrm{~m} \text { transect. } \\
\text { Exuviae collecting on } 27 \text { July from an area of about } 50 \mathrm{~m}^{2}\end{array}$ \\
\hline $\begin{array}{l}\text { Information on the species in the } \\
\text { locality }\end{array}$ & $\begin{array}{l}\text { synthetic information on the occurrence of the species in the locality } \\
\text { Species found at the site in } 2014 \text {, with a low abundance }\end{array}$ \\
\hline Observation dates & $\begin{array}{l}\text { dates of all observations } \\
25.07 .2020,2.08 .2020,10.08 .2020\end{array}$ \\
\hline
\end{tabular}


Table 6 shows an example of how to fill in a "Conservation status of the species" sheet.

Table 6. Conservation status of the species

\begin{tabular}{|c|c|c|c|}
\hline Parameter/ indicators & Indicator value and commentary & \multicolumn{2}{|c|}{ Assessment } \\
\hline \multicolumn{4}{|c|}{ Population } \\
\hline Exuviae density & $\begin{array}{l}\text { indicator value: } 2.8 / 10 \mathrm{~m}^{2} \\
\text { description: sample (14 exuviae) of Stratiotes aloides leaves, } \\
\text { collected from } 50 \mathrm{~m}^{2} \text { on } 27 \text { July }\end{array}$ & $\mathrm{FV}$ & \multirow{2}{*}{ FV } \\
\hline Number of adults & $\begin{array}{l}\text { indicator value: } 10 / 100 \mathrm{~m} \\
\text { description: Specimens were counted in a } 100 \mathrm{~m} \text { transect. The result } \\
\text { of the inspection on } 12 \text { August The number of specimens was high }\end{array}$ & FV & \\
\hline \multicolumn{4}{|c|}{ Habitat } \\
\hline $\begin{array}{l}\text { The area of the water } \\
\text { body covered by } \\
\text { Stratiotes aloides }\end{array}$ & $\begin{array}{l}\text { indicator value: } 41 \mathrm{~m}^{2} \\
\text { description: the area was measured on } 27 \text { July }\end{array}$ & FV & \multirow{4}{*}{ FV } \\
\hline $\begin{array}{l}\text { Presence of dense and } \\
\text { undivided Stratiotes } \\
\text { aloides patches }\end{array}$ & $\begin{array}{l}\text { indicator value: determination of the nature of } S \text { aloides patches on } \\
\text { a three-stage scale: optimal habitat } \\
\text { description/ a rationale for the assessment: Stratiotes aloides forms } \\
\text { one continuous, dense patch within the water body }\end{array}$ & FV & \\
\hline $\begin{array}{l}\text { Succession in a water } \\
\text { body }\end{array}$ & $\begin{array}{l}\text { indicator value: determination of water body succession on a three- } \\
\text { stage scale: optimal habitat } \\
\text { description/ a rationale for the assessment: no replacement of } \\
\text { Stratiotes aloides by other water plants or overgrowing of the water } \\
\text { body is observed }\end{array}$ & FV & \\
\hline Anthropopressure & $\begin{array}{l}\text { indicator value: determination of anthropopressure on a three-stage } \\
\text { scale: low } \\
\text { description/ a rationale for the assessment: no works that may affect } \\
\text { the habitat are carried out. Currently the area is not being } \\
\text { transformed by human. Recreational fishing activities have been } \\
\text { forbidden }\end{array}$ & FV & \\
\hline Conservation prospects & $\begin{array}{l}\text { brief forecast of the population and habitat condition of the species } \\
\text { on the site over the next } 10 \text { to } 15 \text { years: The conservation status of } \\
\text { the Aeshna viridis population and habitat within the surveyed water } \\
\text { body may change slightly within } 10-15 \text { years. Succession in the } \\
\text { water body seems to be very slow, but it cannot be excluded that } \\
\text { that process will accelerate. At present, however, the population of } \\
\text { the } A \text {. viridis at this site does not seem to be at risk }\end{array}$ & & U1 \\
\hline Overall assessment & & & FV \\
\hline
\end{tabular}

Table 7 shows an example of how to fill in a sheet for any additional information, which is also very valuable.

Table 7. Other information

\begin{tabular}{ll}
\hline & $\begin{array}{l}\text { other observed animal and plant species listed in the Habitats and Birds } \\
\text { Directives, endangered and rare species, protected species (indicate the } \\
\text { abundance on the scale: abundant, medium, rare) } \\
\text { Oeucorrhinia pectoralis is listed in the Convention on the Conservation of European } \\
\text { Wildlife and Natural Habitats (Annex II), as well as the Fauna-Flora-Habitats } \\
\text { Directive (Annex IV). The species is rare here }\end{array}$ \\
\hline Alien and invasive species & $\begin{array}{l}\text { alien and invasive species observed } \\
\text { No alien or invasive species were observed }\end{array}$ \\
\hline Protective measures currently & $\begin{array}{l}\text { e.g. strict protection, mowing, grazing and other } \\
\text { being taken }\end{array}$ \\
\hline & $\begin{array}{l}\text { information relevant to further monitoring planning (the way the work is carried } \\
\text { out; indicators that should be used in monitoring, regionally optimal research } \\
\text { time, etc.) } \\
\text { Due to the nature of the water body, exuviae can be collected almost } \\
\text { exclusively from the shore or at a very short distance from it. The optimal date } \\
\text { for exuviae collecting is between } 15 \text { and } 25 \text { July }\end{array}$ \\
\hline Other remarks/other observations & $\begin{array}{l}\text { all information relevant for the interpretation of results, e.g. weather anomalies } \\
\text { None }\end{array}$ \\
\hline
\end{tabular}




\section{CONCLUSIONS}

The presented methodology is relatively simple, as it does not include netting for larvae, which may involve both technical problems and the need to have specialist knowledge of the colour pattern variation of larvae in the family Aeshnidae. Presented methods are non-invasive. The assessment of the status of a habitat can be considered relatively simple due to the extremely pronounced habitat preferences of Aeshna viridis. However, a fieldwork may be difficult due to the nature of water bodies that inhabit the species. It is worth adding that due to the fact that $A$. viridis is the only European dragonfly species fully dependent on the presence of single macrophyte species (Askew 1988; Suhonen et al. 2013), it is impossible to adapt the methodology presented in this paper to other European dragonflies.

In conclusion, the methodology presented needs to be tested in the field in order to verify the validity of its assumptions.

\section{ACKNOWLEDGEMENTS}

I would like to thank dr hab. Paweł Buczyński from the Maria Curie-Skłodowska University in Lublin for his valuable comments on the earlier version of this paper.

\section{REFERENCES}

Andersen E., Nilsson B., Sahlén G. 2016. Survival possibilities of the dragonfly Aeshna viridis (Insecta, Odonata) in southern Sweden predicted from dispersal possibilities. J. Insect Conserv. 20(2), 179-188.

Askew R.R. 1988. The dragonflies of Europe. Colchester, Harley Books.

Bernard R. 2012. Zalotka większa Leucorrhinia pectoralis (Charpentier, 1825), w: Monitoring gatunków zwierząt. Przewodnik metodyczny, red. M. Makomaska-Juchiewicz, cz. 2. Warszawa, GIOŚ, 68-94. [in Polish]

Bernard R., Buczyński P., Tończyk G., Wendzonka J. 2009. Atlas rozmieszczenia ważek (Odonata) w Polsce. Poznań, Bogucki Wyd. Nauk. [in Polish]

Bernard R., Michalczuk W. 2012. Łątka ozdobna Coenagrion ornatum (Sélys, 1850), w: Monitoring gatunków zwierząt. Przewodnik metodyczny, red. M. Makomaska-Juchiewicz, cz. 2. Warszawa, GIOŚ, 38-67. [in Polish]

Borkenstein A., Schröter A., Jödicke R. 2016. Aeshna viridis is an early bird - matutinal matings in a crepuscular species (Odonata: Aeshnidae). Odonatologica, 45(1/2), 37-56.

Borkowski A. 1999. Ważki (Odonata) byłego województwa jeleniogórskiego z uwagami do aktualnego stanu badań, zagrożeń oraz potrzeb ochrony [Dragonflies (Odonata) of the former Jelenia Góra District with evaluation of the actual status of knowledge, endargement and protection]. Przyr. Sudetów Zach. 2, 37-56. [in Polish]

Boudot J.P., Kalkman V.J. (eds.) 2015. Atlas of the dragonflies and damselflies of Europe. The Netherlands, KNNV Publishing.

Bried J.T., D'Amico F., Samways M.J. 2012. A critique of the dragonfly delusion hypothesis: why sampling exuviae does not avoid bias. Insect Conserv. Divers. 5(5), 398-402.

Brunken H., Hein M., Klugkist H. 2012. Auswirkungen ökologischer Grabenräumung auf Fische und die Grüne Mosaikjungfer (Aeshna viridis) in Bremer Natura-2000-Gebieten. Nat. Landsch. 87(8), 370-375. 
Buczyński P. 2012. Dragonflies (Odonata) of the left-bank Bug River valley between Włodawa and Kodeń (middle-eastern Poland). Acta Biol. 19, 47-69.

Buczyński P., Górka M., Buczyńska E. 2015. Has Aeshna viridis Eversmann, 1836 (Odonata: Aeshnidae) really disappeared from southern Poland (East-Central Europe)? Pol. J. Entomol. 84(1), 33-47.

Corbet P.S. 1999. Dragonflies: Behaviour and Ecology of Odonata. Colchester, Harley Books.

de Jong T.H. 1999. De Groene glazenmaker (Aeshna viridis) in de provincie Utrecht. Brachytron 3(2), 11-17.

Dijkstra K.D.B., Lewington R. 2014. Libellen Europas. Der Bestimmungsführer. Bern, Haupt Natur.

Flenner I.D.A., Sahlén G. 2008. Dragonfly community re-organisation in boreal forest lakes: rapid species turnover driven by climate change? Insect Conserv. Divers. 1 (3), 169-179.

Fliedner H. 1996. On the oviposition of Aeshna viridis Eversm. (Anisoptera: Aeshnidae). Notul. Odonatol. 4(7), 122-123.

Frank M. 2014. Ein neues, großes bodenständiges Vorkommen der Grünen Mosaikjungfer (Aeshna viridis Eversmann, Odonata: Aeshnidae) an den Schönberger Torfstichen (Nordwestmecklenburg). Virgo 17(1), 42-45.

Gerard J. 2006. Krabbenscheer en Groene glazenmakers (Aeshna viridis) in de Peizermaden. Brachytron 8(2), 25-30.

Glitz D., Hohmann, H.J., Piper W. 1989. Artenschutzprogramm Libellen in Hamburg. Nat.schutz Landsch.pfl. Hambg. 26, 1-92.

Herder J., Termaat T., Valentini A. 2013. Environmental DNA als inventarisatiemethode voor libellen. Vlinders 28(2), 22-24.

Kalkman V., Kalninš M., Bernard R. 2015. Aeshna viridis Eversmann, 1836, in: Atlas of the European dragonflies and damselflies, eds. J.-P. Boudot, V. Kalkman. The Netherlands, KNNV Publishing, 167-168.

Kalkman V.J., Boudot J.P., Bernard R., Conze K.J., De Knijf G., Dyatlova E., Ferreira S., Jović M., Ott J., Riservato E., Sahlen G. 2010. European Red List of Dragonflies. Luxembourg, EUR-OP, 14.

Karlsson T. 2018. Biogeografisk uppföljning av grön mosaikslända Aeshna viridis - inventering och metodiktest 2017. Länsstyrelsen Östergötland. Rapport 6.

Kastner F., Buchwald R., Biedermann R. 2018. Occurrence of Aeshna viridis in marsh ditches in relation tohabitat conditions (Odonata: Aeshnidae). Int. J. Odonatol. 21(3-4), 205-219.

Kastner F., Münkenwarf M., Buchwald R. 2011. Zum Vorkommen der FFH-Libellenart Aeshna viridis Eversmann, 1836 (Odonata: Aeshnidae) in Krebsscherengräben der Hunte- und Wesermarsch, Niedersachsen. Drosera 2010 (1/2), 103-108.

Klugkist H., Haacks M., Kruse A. 2015. Aeshna viridis Eversmann, 1836. Libellula, Supplement 14, 162-165.

Mauersberger R., Bauhus S., Salm P. 2005. Zum Vorkommen der Grünen Mosaikjungfer (Aeshna viridis Eversmann) im Nordosten Brandenburgs (Odonata: Aeshnidae). Natursch. Landschaftspfl., Brandenburg 14(1), 17-24.

Münchberg P. 1956. Zur Bindung der Libelle Aeschna viridis Eversm. an die Pflanze Stratiotes aloides L. (Odon.). Nachrichtenbl. Bayer. Ent. 5(12), 113-118.

Norling U., Sahlén G. 1997. Odonata, dragonflies and damselflies, in: The aquatic insects of North Europe, vol. 2, ed. A. Nilsson. Stenstrup, Apollo Books, 13-65.

Pawlak S. 2019. Nowe stanowiska żagnicy zielonej Aeshna viridis Eversmann, 1836 (Odonata: Aeshnidae) w dolinie górnej Prosny (Wysoczyzna Wieruszowska) [New habitats of the Green Hawker Aeshna viridis Eversmann, 1836 (Odonata: Aeshnidae) in the Upper Prosna Valley (Wieruszów Upland)]. Odonatrix 15(6), 1-7. [in Polish]

Peters G. 1987. Die Neue Brehm-Bücherei Bd. 585. Die Edelibellen Europas, Aeshnidae. Wittenberg Lutherstadt, Ziemsen. 
Raebel E.M., Merckx T., Riordan P., Macdonald D.W., Thompson D.J. 2010. The dragonfly delusion: why it is essential to sample exuviae to avoid biased surveys. J. Insect. Conserv. 14(5), 523-533.

Rantala M.J., IImonen J., Koskimäki J., Suhonen J., Tynkkynen K. 2004. The macrophyte, Stratiotes aloides, protects larvae of dragonfly Aeshna viridis against fish predation. Aquatic Ecol. 38(1), 77-82.

Rantalainen E., Kanervo E. 1928. Aeshna viridiksen esiintymisestä ja elintavoista Suomessa. Luonnon Ystävä 32, 161-170.

Rassi P., Alanen A., Kanerva T., Mannerkoski I. 2001. Threatened species in Finland in 2001 Helsinki, Ministry of the Environment and Finnish Environment Institute.

Roelofs J.G.M. 1991. Inlet of alkaline river water into peaty lowlands: effects on water quality and Stratiotes aloides L. stands. Aquat. Bot. 39(3-4), 267-293.

Sahlén G. 2006. Manual för basinventering av trollsländor. Stockholm, Naturvårdsverket, 5-7.

Smolders A.J.P., Lamers L.P.M., den Hartog C., Roelofs J.G.M. 2003. Mechanisms involved in the decline of Stratiotes aloides L. in The Netherlands: sulphate as a key variable. Hydrobiologia 506, 603-610.

Smolders A.J.P., Roelofs J.G.M., Hartog C. den. 1996. Possible causes for the decline of the Stratiotes aloides (Stratiotes aloides L.) in the Netherlands. Arch. Hydrobiol. 136(3), 327-342.

Søgaard B., Holmen, M., Rabjerg S., Nielsen O.F., Holm T.E. 2011. Overvågning af guldsmede. Teknisk anvisning til ekstensiv overvågning fra DCE's Fagdatacenter for Biodiversitet og Terrestrisk natur (A06), 1-5.

Sternberg K. 2000. Aeshna viridis Eversmann 1836, in: Die Libellen Baden-Württembergs. Band 2. Großlibellen (Anisoptera), eds. K. Sternberg, R. Buchwald. Literatur. Stuttgart, Ulmer, 110-114.

Strzałek M., Koperski P. 2009. The Stratiotes aloides L. stand as a habitat in oxbow lake Bużysko. Aquat. Bot. 90(1), 1-6.

Suhonen J., Suutari E., Kaunisto K.M., Krams I. 2013. Patch area of macrophyte Stratioites aloides as a critical resource for declining dragonfly Aeshna viridis. J. Insect. Conserv. 17(2), 393-398.

Suutari E., Rantala M.J., Salmela J., Suhonen J. 2004. Intraguild predation and interference competition on the endangered dragonfly Aeshna viridis. Oecologia 140(1), 135-139.

Suutari E., Salmela J., Paasivirta L., Rantala M.J., Tynkkynen K., Luojumaki M., Suhonen J. 2009. Macroarthropod species richness and conservation priorities in Stratiotes aloides (L.) lakes. J. Insect. Conserv. 13(4), 413-419.

Tarkowska-Kukuryk M. 2006. Water soldier Stratiotes aloides L. (Hydrocharitaceae) as a substratum for macroinvertebrates in a shallow eutrophic lake. Pol. J. Ecol. 54(3), 441-451.

Wendzonka J. 2005. Klucz do oznaczania dorosłych ważek (Odonata) Polski. Odonatrix 1 (supplement) 1-26. [in Polish]

\section{PROPOZYCJA METODYKI MONITORINGU ŻAGNICY ZIELONEJ Aeshna viridis Eversmann, 1836 (Odonata: Aeshnidae)}

\footnotetext{
Streszczenie. Żagnica zielona (Aeshna viridis) jest gatunkiem ważki z rodziny żagnicowatych (Aeshnidae), uwzględnionym w załączniku II Konwencji berneńskiej, a także załączniku IV Dyrektywy siedliskowej. Ograniczenie zasięgu występowania i liczebności żagnicy wiąże się z silną zależnością tego gatunku od osoki aloesowatej (Stratiotes aloides) i wynika ze spadku liczby odpowiednich siedlisk. Dotychczas próby opracowania metodyki monitoringu tego gatunku podejmowano w kilku europejskich krajach, między innymi w Szwecji, Danii oraz Holandii. W niniejszym artykule przedstawiono propozycję metodyki monitoringu opartego na ocenie wskaźników stanu populacji w postaci zagęszczenia wylinek oraz liczby osobników dorosłych oraz wskaźników stanu siedliska: powierzchni zbiornika pokrytej przez osokę aloesowatą, obecności zwartych łanów osoki aloesowatej, sukcesji w zbiorniku wodnym oraz
} 
antropopresji. Koncepcję metodyki oceny stanu populacji oparto na obserwacji osobników dorosłych oraz zbiorze wylinek, unikając odłowu larw, między innymi z powodu inwazyjności takiego postępowania oraz konieczności posiadania specjalistycznej wiedzy podczas identyfikacji gatunku. Z kolei koncepcja metodyki oceny stanu siedliska oparta jest na silnym związku żagnicy zielonej z osoką aloesowatą. Proponuje się prowadzenie monitoringu żagnicy zielonej na minimum kilkunastu obszarach badawczych w obrębie kraju, w cyklu dwuletnim. Przedstawiona propozycja metodyki monitoringu wymaga przeprowadzenia badań pilotowych w obrębie stanowisk żagnicy zielonej $w$ celu oceny słuszności postawionych założeń w metodyce prowadzenia monitoringu tego gatunku.

Słowa kluczowe: żagnica zielona, Aeshna viridis, monitoring. 
